\title{
非構造格子を用いた高潮・波浪・潮汐結合モデルによる ハリケーンカトリーナ高潮場再現計算
}

\author{
Hurricane Katrina Storm Surge Hindcast \\ Using a Coupled Storm Surge, Wind Wave and Tidal Current Model on an Unstructured Grid
}

文屋信太郎 ${ }^{1} ・ \exists$ ネスウェスタリンク ${ }^{2}$

Shintaro Bunya, Joannes J. Westerink

\begin{abstract}
Hurricane Katina (2005) brought enormous damage to coastal protection systems in southern portions of the states of Louisiana and Mississippi, USA. In efforts to recover the devastated areas, construction of new systems to protect the areas from possible storm surge in the future has been a very urgent task. In this work, we develop a coupled storm surge, wind wave, riverine flow and tidal current model being used to design the new protection systems. The computational model employs the finite element method for the riverine, tide and storm surge model and takes advantage of unstructured grids to obtain precise estimation of possible surge heights from 100-year level storms. Observed hydrographs and high water marks during the hurricane are used to validate the developed model. The validation shows that the model is capable of reproducing the storm surge induced by the hurricane with good accuracy. The model is also found to be useful to understand how the hurricane caused the unprecedented surge levels.
\end{abstract}

\section{1. はじめに}

2005年8月23日にバハマ南東で発生し，その後ハリケー ンカトリーナとなった熱帯低気圧は，8月29日1110Zに 米国ルイジアナ州に上陸した。同ハリケーンによっても たらされた損害は，被害額においてはアメリカ合衆国を 襲ったハリケーンの中で歴代 1 位，死者数は歴代 5 位と, 歴史的なむのとなった。これらの被害は主に暴風と高潮, 高波によって発生したものであるが，その中でも $8 \mathrm{~m}$ 超 の水位が観測された高潮とそれに伴う洪水による被害が 最む大きかった. 同ハリケーンの来襲によってニューオー リンズ市やその周辺地区を防護する堤防等海岸施設は大 きく損壊した。同ハリケーンが去った後, 損害を受けた 海岸防護施設の応急修復作業が開始された。 また，発生 した高潮，洪水について情報を得るために高潮線の収集 等の調査がアメリカ陸軍工兵隊 (USACE) の管理の下 で行われた.ここで得られた情報は後に示すように高潮・ 洪水数值モデルの検証データとしても貴重なものとなっ た.

損害を受けた地区を復興し，住民の帰還を促すために は, 海岸防護システムの再建が不可欠である. 新防護シ ステムの設計・施工を担当する USACE は多数の専門家 からなる the Interagency Performance Evaluation Task

1 正 会 員 博士(環境学)東京大学講師大学院工学系研究科シス テム創成学專攻
Force（IPET）を組織し，100年レベルの防護システムを 設計するべく, 研究・調查を進めた. IPETでは堤防シ ステムの設計に必要となる想定高潮水位を算出するため に高潮場・波浪場・潮汐を考慮した高潮・洪水数值モデ ルの構築を行った.このプロジェクトにおいて我々のグ ループは非線形浅水長波方程式を主な支配方程式とする 長波・潮汐モデルを提供し, 別グループが提供する波浪 モデルとの結合モデルを構築した．この数值モデルで得 られた想定最大水位を参考にして100年レベル防護シス テムの設計が行われた. 現在2011年の完成に向けて施工 が進められている.

既存の海洋流れのモデルとしては米国の FEMA, USACE，NWS が開発する SLOSH モデルや Princeton Ocean Model（POM）など多く提案されている。例えば 金ら（2006）はPOM を用いてカトリーナの高潮場を再 現している.しかし，これらはいずれも構造格子を用い たモデルであり, 空間解像度を大幅に変更するにはネス ティング等の操作を必要とし，広い計算領域を解像度を 犠牲にすることなく一度に解くことは容易でない，その 点, 非構造格子を用いた手法は空間解像度を变更するこ とが容易であり, 後に示すように数千 $\mathrm{km}$ 規模の計算領 域の中で数十 $\mathrm{m}$ 規模の水路や陸上の水理障害物を考慮 した計算も可能である。このような利点が非構造格子に はあるものの, その非構造格子の作成には大きなコスト を要することから，これまで，高潮場・波浪場・潮汐を 考慮した実用モデルの開発・検証は遅れてきた。非構造 格子の採用が遅れてきたもうひとつの理由として，格子 
の高い解像度に見合うだけの地形等の入力情報の入手が これまで困難であったことが挙げられる。しかし，近年 の測量・観測技術の向上, GIS 情報に対する需要の増大 を背景に, 入手可能な地理情報が質・量ともに向上して おり, 非構造格子を用いた高解像度の計算を行う環境が 整ってきている.

本稿ではこのような状況下で開発された非構造格子を 用いた高潮場・波浪場・潮汐結合モデルを紹介する。ま た, この数值モデルの検証の一環として行ったハリケー ンカトリーナによる高潮場の再現計算を行い, 推算值之 観測値との比較を通して数值モデルの精度を検証する.

\section{2. 高潮・波浪・潮汐結合モデル}

ここでは構築した数値モデルについて説明する. 本結 合モデルは深海での波浪場を計算するWAM モデル, 陸棚上の波浪場を計算する STWAVE モデル, 高潮・潮 汐を計算する ADCIRC モデルから成る. 以下にそれぞ れについて説明する.

\section{(1) 外洋の波浪モデル}

外洋深海域の波浪場を算出するために WAM モデル (Gunther，2002）を用いる. WAM モデルはSWAN や WAVEWATCH III モデルに類似のモデルであり, 動的 波作用量平衡式を構造格子上で解く. 風応力, 非線形波 相互作用, 消散, 砕波, 水底摩擦等を考慮する. WAM モデルによって得られた瞬時の wave energy spectrum は 次に示す STWAVE モデルに境界条件として与えられる.

\section{(2) 陸棚上の波浪モデル}

陸棚上あるいは沿岸域の波浪場はSTWAVE モデル （Thompson ら，2004）を用いて算出する. STWAVE モ デルは静的波作用量平衡式を解く差分モデルである. ソー 項には風応力, 非線形波相互作用, 消散, 砕波, 水底 摩擦等が含まれる. STWAVEによって得られた構造格 子上の radiation stress は ADCIRC モデルの非構造格子上 に内挿して与えられる. 静的モデルであるため十分な時 間頻度で再計算を行うよう注意する必要がある.

\section{(3) 高潮・潮汐計算のための海洋モデル}

高潮・潮汐の計算には ADCIRC (Advanced Circulation）モデルを用いる. ADCIRC モデルは我々の グループが開発する洪水・氾濫解析が可能な浅水流モデ ルである. 海洋・湖沼・河川の流れと輸送問題を解析対 象とする. 水平2次元バロトロピック流を計算対象とす る場合, 非線形浅水方程式を主な支配方程式として用い る. 計算格子には三角形 1 次要素から成る非構造格子を 用いる. 数值解法の詳細については Westerink ら（2008） を参照されたい，今回構築された高潮・洪水モデルでは， 風速・気圧分布, 海底・陸上の水深・標高, 底面摩擦係 数 (マニングの粗度係数), 海水の温度膨張による水位
上昇, 潮汐計算のための水位境界条件, 潮汐ポテンシャ ル, 主要河川の流量, 波応力（radiation stress）を入力 条件として与える。このうち radiation stress については 先に説明した STWAVE モデルから得る. 出力は各時刻 ステップにおける水位と流速である.

WAM, STWAVE, ADCIRC を結合したモデルの計算の 流れを図一に示した．この図に示したように最終的な高 潮場を得るまでに ADCIRCによる計算を3回, STWAVE 及び WAM の計算をそれぞれ1回行う，ADCIRCによる 計算を3度行うのはSTWAVEによる計算が高潮場の水 位に依存するためである. 二度目の波浪場を考慮せずに 得られた水位分布をSTWAVEに渡して波浪場を推算し， そこで得られる radiation stress をADCIRCに戻して wave setup を考慮した最終的な高潮場を算出する.

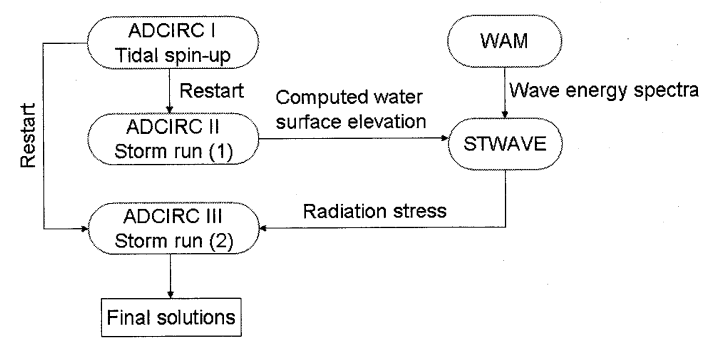

図-1 高潮・波浪・潮汐結合モデルの計算の流れ

\section{3. ハリケーンカトリーナ再現計算によるモデル検証}

前節で示した計算モデルにカトリーナの計算条件を与 え, 高潮場の推算結果と観測値を比較することでモデル の再現性を検証する.

\section{(1) 入力条件}

以下に主に ADCIRC モデルの入力条件を述べる.

風速デー夕はNOAA の H*WIND モデルによって再現 したカトリーナの風速を基に, Ocean Weather Inc.の IOKA data assimilation 適用して観測值に同化したもの を用いる．観測值に対してデータ同化手法を適用してい るため得られた風速場の精度は高い。気圧分布は Holland らの数值モデルを用いて求める. デー夕同化は 行われていない.

使用した非構造格子を図-2，3に示した。計算領域は 西大西洋, カリブ海，メキシコ湾を含む．格子点の $90 \%$ 以上は本計算での関心領域であるルイジアナ・ミシシッ ピ州付近に配置されている. 両図に示されているように 数千 $\mathrm{km}$ 規模の大領域を扱いつつも, 関心領域での解像 度は確保されて抢り, 非構造格子の有利性が活かされて いる. 格子点間隔は大きいもので数十 $\mathrm{km}$ ，小さいもの で $30 \mathrm{~m}$ 程度である。計算コストが $10 \%$ 増大することを 許すことによって大西洋までを含めた大規模な計算が可 
能となっている．関心領域から離れた場所に人工的な開 境界を設置するため, 境界における非物理的な反射波の 影響をほぼ無視できる程度に小さく抑えることができ, また, 潮汐の計算においてはより大スケールな共振モー ドを捉えることができる（Westerink ら，2008）. 図-4に 示したルイジアナ・ミシシッピ両州周辺の水深及び標高 から，陸棚上の barrier islandなどの細かな水深・標高の 変化が考慮されていることがわかる. 陸上は標高数十 $\mathrm{m}$ までの地点を計算領域に含めているため, 陸上における 洪水・氾濫解析が可能である. 水深・標高デー夕には E TOPO5, Atlas LIDAR, DEM 等を用いた.

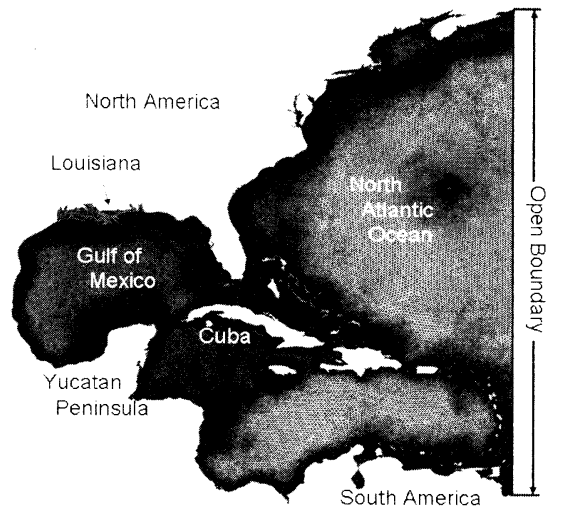

図-2 カトリーナ再現計算に用いた大規模・高解像度の非構 造格子. 格子点数 $2,137,978$, 要素数 $4,184,778$.

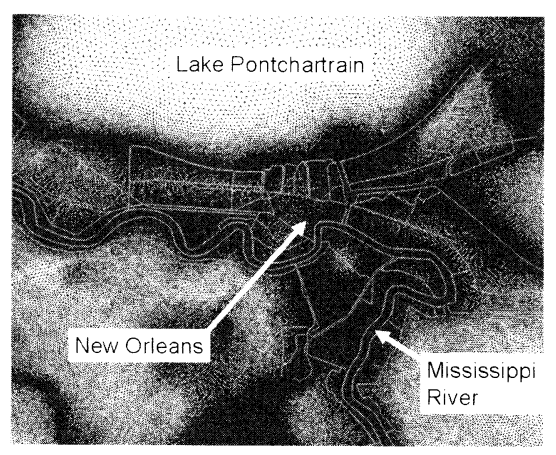

図-3 ニューオーリンズ周辺の非構造格子. 灰色実線は広頂 堰の流量公式で考慮する堤防等水理的障害物.

浅水流計算において重要な水底摩擦にはマニング則を 用いた. 粗度係数は GAP P NLCD から植生, 土地利用 状況を推定して求めた。

潮汐偏差を考慮するために, 図-2に示した海中の開境 界において $\mathrm{M}_{2}, \mathrm{~S}_{2}, \mathrm{~K}_{1}, \mathrm{O}_{1}, \mathrm{~N}_{2}, \mathrm{~K}_{2}, \mathrm{Q}_{1}, \mathrm{~K}_{1}$ 分潮の水 位を与えた。 さらに対応する潮汐ポテンシャルを外力項 として与えた.

ADCIRC モデルによる計算においては $\Delta t=1 \mathrm{~s}$, 海中
の渦動粘性係数を $10 \mathrm{~m}^{2} / \mathrm{s}$, 海水の熱膨張による水位の 上昇効果を $0.37 \mathrm{~m}$ として与えた.

図-5にWAM 及び STWAVE モデルのための計算領域 を示した。この図のように大きな radiation stress が予想 された4つの領域で STWAVEによる波浪場計算を行っ た. 格子間隔は $200 \mathrm{~m}$ とした. STWAVEによる波浪場 計算は8/28 12Z から2日間, 1800秒毎に計算し, その結 果を時間および空間方向に線形内挿し, ADCIRC 計算 に用いた。なお，900秒毎の計算結果との比較では顕著 な差異は見られなかった。

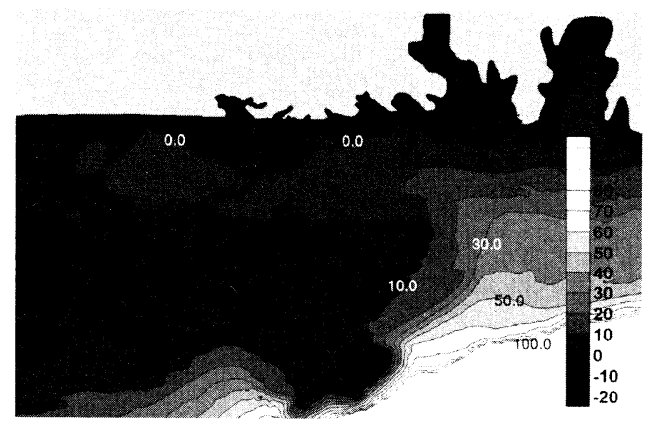

図-4 非構造格子で表現されている水深および標高.（28.85$31.04 \mathrm{~N}, 87.70-90.88 \mathrm{~W})$

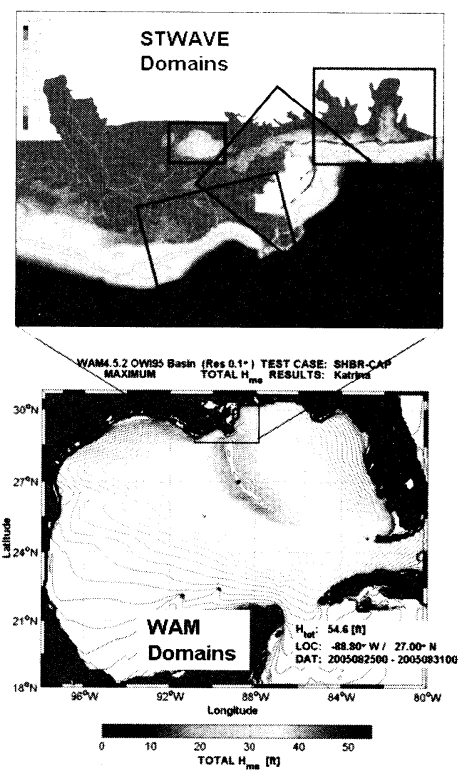

図-5 WAM 及び STWAVE モデルの計算領域.

\section{(2) 計算結果}

上記の条件で行った計算の結果を以下に示す.図-6に 観測ステーションで観測された水位ハイドログラフと計 算結果の比較を示した。観測值においてデータの無い区 間は久測部である。高潮偏差, 潮汐ともに推算値は観測 
值に良好に一致している. Bayou Labranch において全時 間領域において $0.3 \mathrm{~m}$ 程の均等な過大評価が見られるの は観測值の基準面のずれであると考えられる.

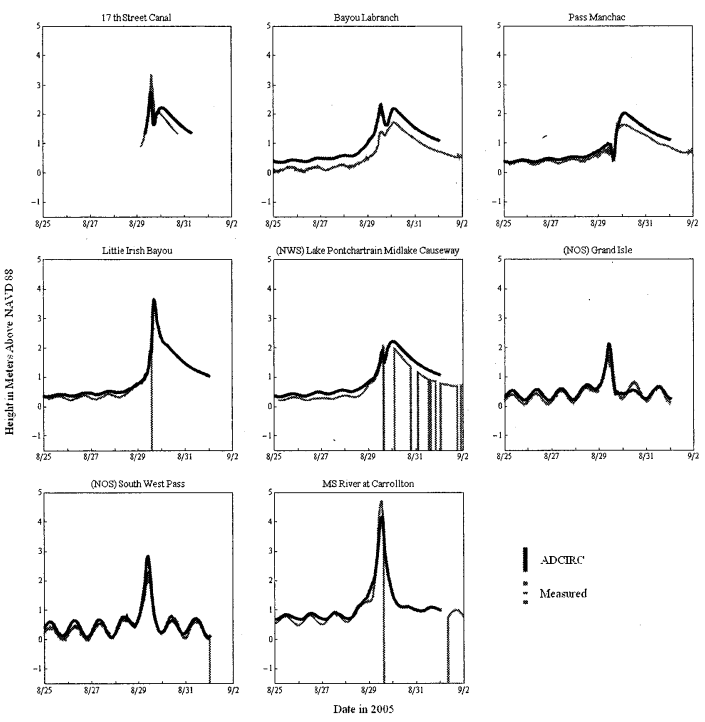

図-6 8つの観測ステーションで観測された水位ハイドログ ラフ(灰線)之計算結果(黒線)の比較. 縦軸の単位は $\mathrm{m}$.

図-7にハリケーン作用中の最大水位の推算值を示す. “I”で示したミシシッピ川下流域には高潮循環流が東 岸の堤防で遮られたために生じた急激な水位上昇が現れ ている。“II”で示した Bay St. Louis から Gulfport, Biloxi に掛けてまでの領域には7-8 $\mathrm{m}$ の水位上昇が見ら れる。この領域の天文潮振幅は高々数十 $\mathrm{cm}$ であるから, 水位上昇はほぼすべてが高潮偏差によるものである.

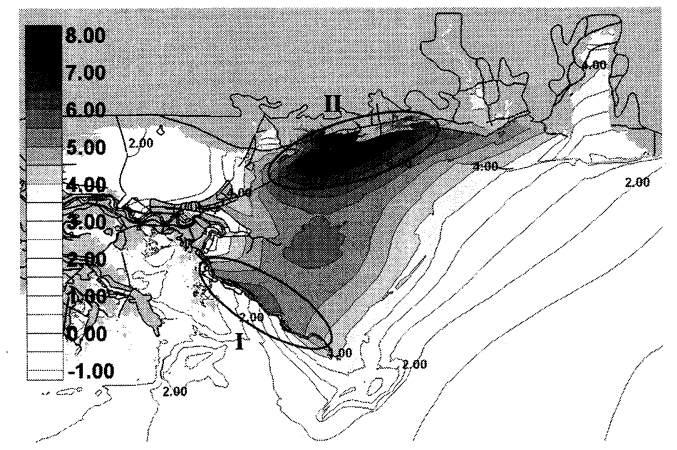

図-7 ハリケーン作用中の最大水位の推算值. 色コンターが 水位を表し，単位は $\mathrm{m}$.

図-7のように得られた最大水位の推算値を206地点に おいて収集された最大水位（high water mark）の観測値 と比較したものが図-8である. 最大水位は $1 \mathrm{~m}$ 程度から $8 \mathrm{~m}$ を超える大きさまで幅広く分布しているが, ごの大
きさにおいて屯ほぼ一定の誤差内で推算できている. 206地点の内, $65 \%$ 以上の地点で誤差が士50 cm であり, また，95\%以上の地点で誤差が士 $1 \mathrm{~m}$ の範囲に収まって いる. 過小評価の原因としては海岸構造物付近の流れの 3次元性を考慮できていないことが挙げられる. 過大評 価の原因としては，高解像度のメッシュであ捉えきれな い住宅などのサブグリッドスケールの構造をすべて底面 摩擦として考慮していることの限界などが考えられる. また，観測值自体も䛊差を含むものと思われる，なお， これらの high water mark の多くは陸上で収集されたも のであるから，推算值との比較を行う場合には数值モデ ルが氾濫・洪水を扱えるモデルである必要がある。

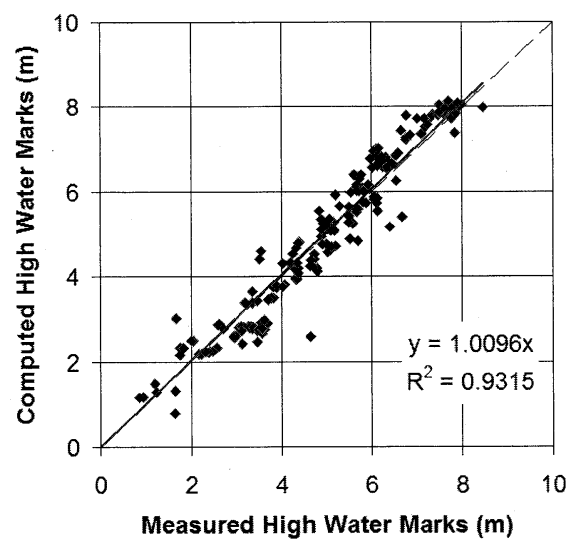

図-8 ハリケーン作用中の最大水位の推算値と観測值を 206 地点において比較.

波浪場の高潮場への寄与を調べるために, radiation stress を考慮した場合としなかった場合との最大水位の 差を図-9に示した。図中“I”で示したミシシッピ川河 口付近, “II” で示した Chandeleur islands 付近, “III” で 示した他の barrier islands 付近では水深変化が急である ため砕波による radiation stress が増大し, それらと海岸 線との間の極浅海域に wave setup 効果が現れていると 解釈できる. 従ってこれらの領域の水深・標高を正しく モデル化することが重要であると考える. また wave setup の効果はこの図からは海岸線では0.2-0.3 m 程度で あったと読み取れる. 局所的には $0.8 \mathrm{~m}$ 程度の比較的大 きな効果が現れている.

潮汐を考慮した場合としなかった場合との最大水位の 差を図-10に示した。非常に大きな高潮偏差が観測され た Bay St. Louis や Biloxi を含むミシシッピ州沿岸では 潮汐によって最大水位が $0.1-0.2 \mathrm{~m}$ 程押し上げられてい る. 図中“I”で示した English Turn 付近や“II”で示し た Lake Pontchartrain 南岸では最大水位発生時刻が異な るため潮汐の効果が最大水位を押し下げる方向であった 様子が現れている. 
図-11，12には8/29 11Z および $8 / 2914 Z$ における瞬時 の風速べクトルと水位コンター（推算值）を示した。図 -11からは高潮循環流がミシシッピ川東岸の堤防によっ て遮られ，大きな水位勾配を生じている様子が現れてい る.また, より大域的には, 北方の海岸からミシシッピ 川東岸にかけての海岸形状が “く”の字型をしており, これが南東から東寄りの風による吹き寄せ効果による水 塊の移動を受け止めて, 水位上昇を増大させたことが伺 える. 図-12の8/29 14Zの結果からは八リケーンの進行 に伴って南寄りの風が卓越し，ミシシッピ川東岸および その周辺に集められた水塊が吹き寄せ効果によってミシ シッピ州沿岸に押し寄せたこと様子が現れている.

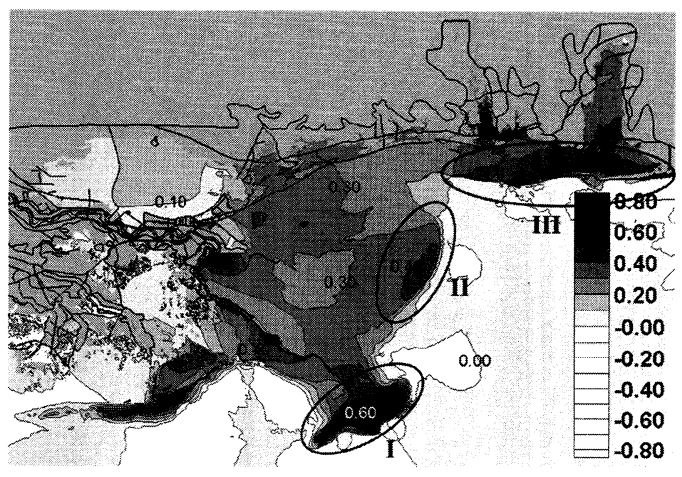

図-9 Radiation stress を考慮した場合と，考慮しなかった場 合との最大水位の差. 単位は $\mathrm{m}$.

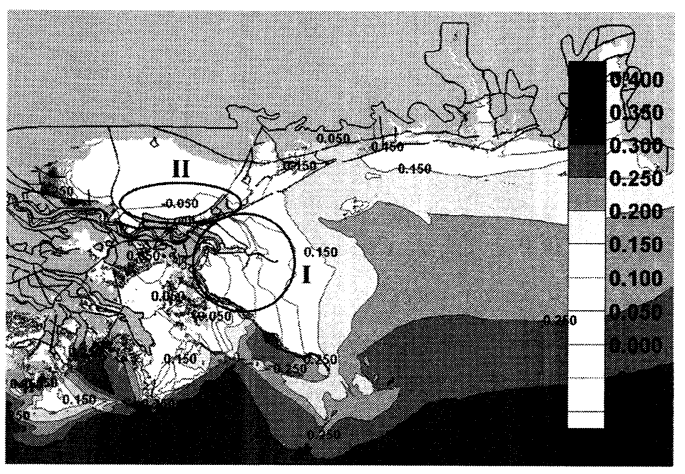

図-10 潮汐を考慮した場合と, 考慮しなかった場合との最 大水位の差. 単位は $\mathrm{m}$.

\section{4. まとめ}

本稿では高潮・波浪・潮汐結合数値モデルを構築し, ハリケーンカトリーナ（2005）の観測データを用いるこ とで再現精度の検証を行った. その結果, この数值モデ ルが高潮・洪水を良好に再現できることが確認できた。 また, 非構造格子の採用は広領域でしかも高解像度な高 潮・洪水モデルの構築に有効であることを示した. 計算 結果の分析からは, カトリーナによって非常に大きな高
潮が発生したのはミシシッピ川東岸の堤防と東に開けた 海岸地形が高潮循環流の遮断と吹き寄せ効果を助長した ためであることが推定された。

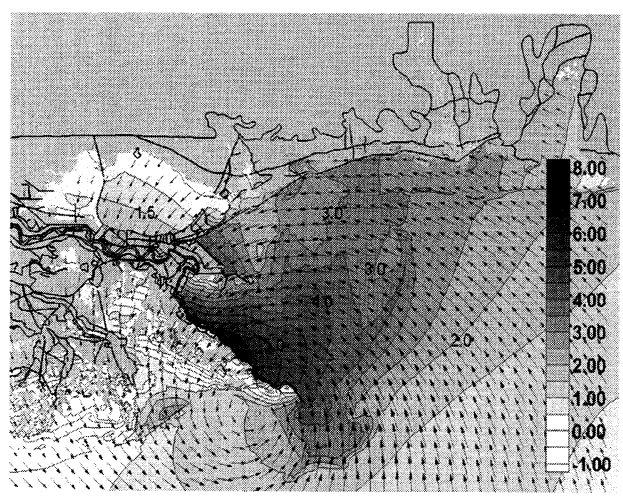

図-11 8/29 11Z における瞬時の風速ベクトルと水位コンター.

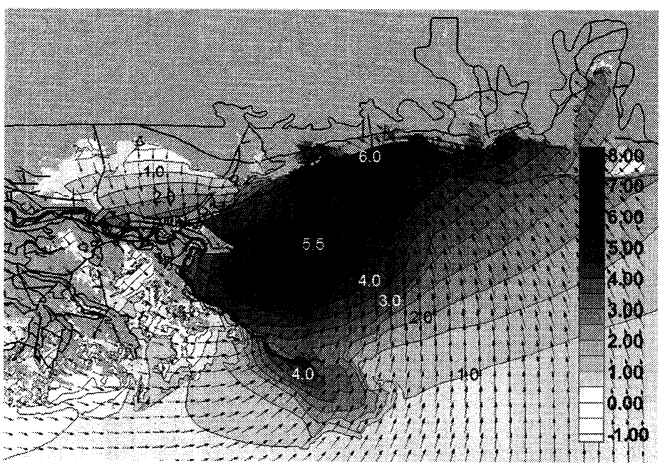

図-12 8/29 14Z における瞬時の風速べクトルと水位コンター.

謝辞：本研究を行うにあたり, USACE IPET プロジェク ト, USACE/FEMA JSC Study, USACE Morphos プロジェ クト,科研費（19860028）の助成・協力を得た。特に USACE 所属 Dr. Jane M. Smith にはSTWAVE モデルの 計算結果を提供頂いた。ここに謝意を表する。

\section{参 考 文 献}

金庚玉・李漢洙・Mohammed Haggag - 山下隆男（2006）：大気・ 波浪・海洋結合モデルによるハリケーンカトリーナの高潮場 のシミュレーション, 第53回海講論文集, pp. 416-420.

Gunther, H. (2002): WAM Cycle 4.5, Institute for Coastal Research, GKSS Research Centre Geesthacht.

Thompson, E.F., J.K. Smith, H.C. Miller (2004): Wave transformation modeling at Cape Fear River Entrance, North Carolina, Journal of Coastal Research, pp. 1135-1154.

Westerink, J.J., J.C. Feyen, J.H. Atkinson, R A. Luettich, C. Dawson, H.J. Roberts, M.D. Powell, J.P. Dunion, E.J. Kubatko, H. Pourtaheri (2008) : A basin to channel scale unstructured grid Hurricane storm surge model applied to southern Louisiana, Monthly Weather Review, Vol. 136 pp. 833864. 